\title{
Use of Biochar-Producing Gasifier Cookstove Improves Energy Use Efficiency and Indoor Air Quality in Rural Households
}

\author{
James K. Gitau ${ }^{1,2, *}$, Cecilia Sundberg ${ }^{3,4}$, Ruth Mendum ${ }^{5}{ }^{\oplus}$, Jane Mutune ${ }^{1}$ \\ and Mary Njenga ${ }^{1,2}$ (D) \\ 1 Wangari Maathai Institute for Peace and Environmental Studies, University of Nairobi, P.O. Box 2905-0065, \\ Nairobi, Kenya; mutheumutune22@gmail.com (J.M.); m.njenga@cgiar.org (M.N.) \\ 2 World Agroforestry Centre (ICRAF), P.O. Box 30677-00100, Nairobi, Kenya \\ 3 Department of Sustainable Development, KTH Royal Institute of Technology, Environmental Science and \\ Engineering (SEED), Teknikringen 10B, SE-10044 Stockholm, Sweden; cecilia.sundberg@abe.kth.se or \\ cecilia.cesu@kth.se \\ 4 Department of Energy and Technology, The Swedish University of Agricultural Sciences, \\ SE-75007 Uppsala, Sweden \\ 5 Office of International Programs, College of Agricultural Sciences, The Pennsylvania State University, \\ 106 Agricultural Administration Building, University Park, PA 16802, USA; rmm22@psu.edu \\ * Correspondence: jameskinyuagitau@gmail.com or j.g.kinyua@cgiar.org; Tel.: +254-7-2277-0790
}

Received: 3 September 2019; Accepted: 25 September 2019; Published: 11 November 2019

\begin{abstract}
Biomass fuels dominate the household energy mix in sub-Saharan Africa. Much of it is used inefficiently in poorly ventilated kitchens resulting in indoor air pollution and consumption of large amounts of wood fuel. Micro-gasification cookstoves can improve fuel use efficiency and reduce indoor air pollution while producing char as a by-product. This study monitored real-time concentrations of carbon monoxide $(\mathrm{CO})$, carbon dioxide $\left(\mathrm{CO}_{2}\right)$ and fine particulate matter $\left(\mathrm{PM}_{2.5}\right)$, and amount of firewood used when households were cooking dinner. Twenty-five households used the gasifier cookstove to cook and five repeated the same test with three-stone open fire on a different date. With the gasifier, the average corresponding dinner time $\mathrm{CO}, \mathrm{CO}_{2}$, and $\mathrm{PM}_{2.5}$ concentrations were reduced by $57 \%, 41 \%$, and $79 \%$ respectively compared to three-stone open fire. The gasifier had average biomass-to-char conversion efficiency of $16.6 \%$. If the produced char is used as fuel, households could save $32 \%$ of fuel compared to use of three-stone open fire and $18 \%$ when char is used as biochar, for instance. Adoption of the gasifier can help to reduce the need for firewood collection, hence reducing impacts on the environment while saving on the amount of time and money spent on cooking fuel.
\end{abstract}

Keywords: gasifier cookstove; indoor air pollution; energy use efficiency; three-stone open fire; firewood; biochar; char

\section{Introduction}

Solid fuels are estimated to be relied on by 2.9 billion people worldwide to meet their cooking needs [1]. In Kenya, 90\% of rural households use wood fuel for cooking and heating [2]. Wood fuel is preferred for its affordability, availability, and convenience [3]. About $2 \%-7 \%$ of global anthropogenic emission of greenhouse gases (GHG) is estimated to be from the production and use of firewood and charcoal [3]. Most of these emissions can be traced back to developing countries as well as emerging economies [4]. 
Use of inefficient biomass cookstoves in indoor environments with limited ventilation leads to household air pollution and is associated with adverse health impacts from incomplete combustion of biomass fuel [5]. Fine particulate matter of less than $2.5 \mu \mathrm{m}$ aerodynamic diameter $\left(\mathrm{PM}_{2.5}\right)$ and carbon monoxide (CO) are the two mostly measured markers of household air pollution $[5,6]$. Globally, 4.3 million people are estimated to die every year from household air pollution [7]. A range of conditions such as acute and chronic respiratory diseases, cardiovascular diseases, low-birth weight and cataracts are associated with household air pollution [8-10]. Environmental impacts also do result as wood is converted into particulate matter, CO, free radicals and other pollutants [11].

Introduction of improved household cookstoves is not only an important strategy for reducing the negative effects of burning solid fuels on health and environment but also for making wood-based energy more sustainable [12-14]. Fuel use is reduced with improved and efficient stoves which consequently reduces carbon dioxide $\left(\mathrm{CO}_{2}\right)$ emission and when sufficiently advanced, it decreases black carbon emission as well [15]. Gasifier cookstove is a pyrolytic stove which produces combustible gases burned to generate heat for household cooking in rural areas of developing countries and char as a by-product [16].

Research has been carried out which have shown gasifier to be better than three-stone open fire in terms of fuel use efficiency and concentrations of gases and particles [17]. However, most of the improved stove studies have been standardized or are carried out in laboratories which do not represent real conditions under which these stoves are used [18]. A few studies have been carried out in or near real-life conditions. For instance use of galvanized gasifier by households in rural Kenya to cook a common meal for a household of five people reduced fuel use by $40 \%$ with the produced char being considered to be fuel and produced $90 \%$ and $45 \%$ less $\mathrm{PM}_{2.5}$ and CO respectively compared to three-stone open fire [17]. Most studies have also not fully assessed the char production aspect of the gasifier. It has been recommended to investigate improved stoves under their context of use with cooking and fuel practices taken into consideration [19]. Therefore, this study aimed to assess pollutant concentrations in the kitchen, energy use efficiency and char production rates when gasifier cookstove is used to cook dinner under real conditions at Kwale County. The objective was to investigate variability between households. A comparison was also made with three-stone open fire.

\section{Materials and Methods}

\subsection{Research Design}

This study was conducted to investigate energy use efficiency and concentrations of $\mathrm{CO}, \mathrm{CO}_{2}$, and $\mathrm{PM}_{2.5}$ in the kitchen/cooking area when gasifier cookstove is used by smallholder farmers in Kwale County. These households were trained and issued with a gasifier. 25 households were selected through randomization to participate in the cooking test with a gasifier cookstove with five of these households repeating the same test during different days with three-stone open fire. Firewood consumption, char produced, and indoor air concentrations of $\mathrm{CO}, \mathrm{CO}_{2}$, and $\mathrm{PM}_{2.5}$ were measured during the cooking exercise.

\subsection{Study Area}

The study was carried out at Waa Ward, Matuga Constituency, Kwale County. Kwale County is about $33 \mathrm{~km}$ South of Mombasa situated at $4.18^{\circ}$ South, 39.45 East and $323 \mathrm{~m}$ above sea level [20]. The County has foot plateau, coastal plain, coastal uplands and Nyika plateau topographical features and a monsoon type of climate with an average temperature of $24{ }^{\circ} \mathrm{C}$. Maize (Zea mays), cassava (Manihot esculenta), cowpeas (Vigna unguiculata) as well as fruit trees such as coconut (Cocos nucifera), mango (Mangifera indica), citrus (Citrus spp.), cashew nut (Anacardium occidentale), avocado (Persea americana), guava (Psidium guajava) are the main crops grown in the area either for subsistence consumption or commercial purposes [21]. Agroforestry is also practiced in the area where 
trees are grown on-farm mainly for the provision of fruit and construction materials and their prunings and offcuts used as cooking fuel.

\subsection{Cookstoves}

A Top-Lit UpDraft (TLUD) gasifier cookstove branded as "GASTOV" (gasifier hereafter) from Kenya Industrial Research and Development Institute (KIRDI) was used in this study (Figure 1). The gasifier is ignited at the top (Figure 2a) and the primary air enters at the bottom and moves up through the packed bed of fuel. Secondary air enters from below into the top section, where it mixes with the gases for combustion. Three-stone open fire has three stones set in a triangular way leaving three openings for loading firewood which burns in the space in-between generating heat that is used either for cooking or warming the house (Figure 2c).

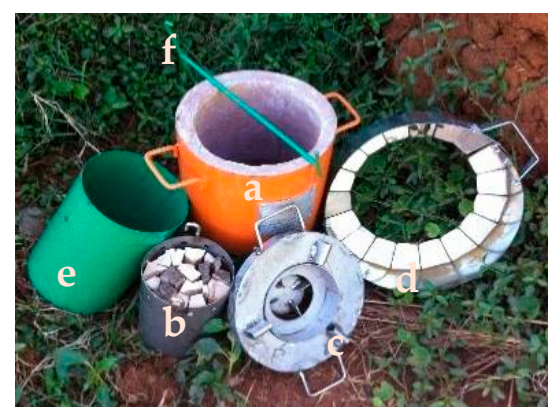

Figure 1. GASTOV. The "GASTOV" gasifier stove has the following parts: (a) an insulated casing with a $5.5 \mathrm{~cm} \times 4.5 \mathrm{~cm}$ air inlet with a door (damper) that can be regulated at half or full height at the bottom, (b) a $19 \mathrm{~cm}$ high fuel canister in the middle, (c) a $6 \mathrm{~cm}$ high gas combustion chamber on top as the main burner, fitted with a skirting (d) to hold the pot in position and protect flames from wind, (e) a charcoal cover (snuffer) used to cool the charcoal by cutting off oxygen, and (f) a canister holder.

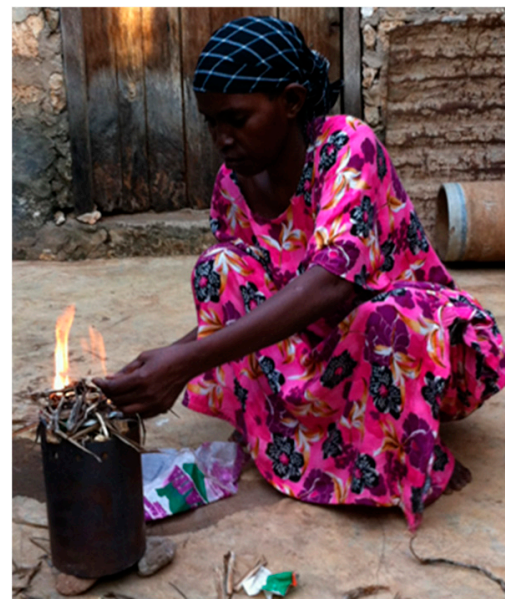

(a)

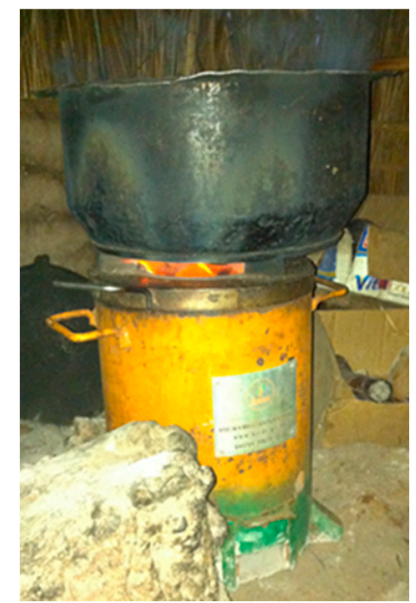

(b)

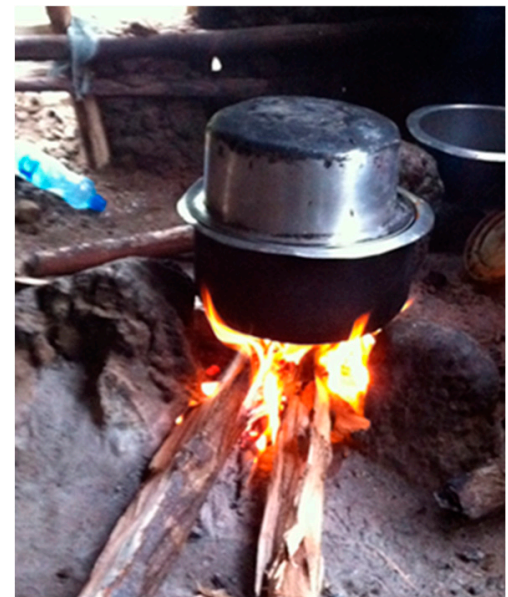

(c)

Figure 2. (a) Lighting fuel in a canister outside; (b) cooking with gasifier; and (c) cooking with three-stone open fire.

\subsection{Selection of Households and Development of Cooking Schedule}

Fifty households had been previously trained and issued with a gasifier for free in the Biochar-Energy project 2016-2018. Follow-up visits were done after every three weeks and an interview conducted after two-three months of the gasifier use to assess how it was being used [22,23]. The objective, activities, and involvement in the participatory cooking experiment were first explained to the 50 households. Thirty households were then randomly selected from the 50 and the first 25 households given priority to participate in the cooking test and the remaining five reserved as 
replacement. Among the 25 households, 20 agreed to participate in the cooking test and five households did not and hence were replaced with the five reserves.

The households with unmodified three-stone open fire and willing to participate in the test with the two stoves were identified from the participating 25 households. The above procedure was repeated picking the first seven households and giving priority to the first five households to participate in the cooking test and the remaining two being reserved as replacement. The five picked households agreed to participate. The selected households were asked to pick the dates they were comfortable to participate in the cooking test, within the 30 days test period. For the households cooking with the two stoves, the cooking dates were set within the same week to avoid much variations in the conditions under which the two tests were performed.

\subsection{Cooking Exercise}

Since the study aimed to measure the concentrations of gases and particles, and energy use efficiency under real practices, the participatory cooking tests involved households cooking a dinner meal of their choice under normal conditions without any interferences. The five households using the two stoves cooked the same type and amount of food using the same type of fuel in both stoves in the same kitchen but on different dates. Activities around fuel preparation such as chopping firewood, the person who prepared the fuel and what he/she used and the person cooking the meal were recorded in the cooking test observation form.

The canister was loaded with firewood and lit from outside in all the households using small pieces of firewood, light biodegradable materials, papers, and a match. The canister was placed on top of either three pieces of stone or wood to ensure that the air holes at the bottom were not blocked hence airflow through the arranged fuel was not interfered with. When the fuel was well lit, the canister was returned to the outer casing in the kitchen using the canister holder, the burner was fixed back, and the cooking started. Three-stone open fire was lit inside the kitchen which is the common practice.

Dying of the flames from the burning biomass in the gasifier fuel canister was the sign that the fuel was charred, and the char was harvested and cooled either in the kitchen or outside. In instances where the fuel charred before the food was ready, the char was poured into the charcoal cover which was then overturned to cover the char to cool. The canister was reloaded with firewood, the above procedures were repeated and cooking continued until the food got ready. In instances where the food got ready before the charring process, whatever the cook did with the stove was recorded.

All the ingredients used to cook the meals were weighed on a top load kitchen scale as well as the cooked food. The char and ash produced were weighed and recorded. Samples of the fuels used, char, and ash produced from the gasifier were collected and stored in khaki papers for laboratory analysis. The cooking experiment started on 3 April 2018 and ended on 3 May 2018. Time for cooking the dinner varied between household and it ranged between 5:14 p.m. and 8:20 p.m.

\subsection{Fuel Consumption}

The weight of fuel used in cooking with the gasifier was calculated as a percentage of gross or net fuel used. Gross fuel is the amount of fuel used including the harvested char while net fuel is the fuel used minus the char produced. The weight of the empty canister, when filled with fresh fuel and produced char were recorded. For three-stone open fire, a pile of firewood was weighed and kept separate and all the fuel used during the cooking experiment was picked from that pile. The amount of fuel withdrawn from three-stone open fire after cooking as well as the weight of firewood remaining in the original pile was weighed and recorded.

\subsection{Measurement of Gases and Particles Concentrations in the Kitchen, Flame Temperature, and Fuel Moisture Content}

The cooks were informed to put off all the stoves in the kitchen three hours prior to the dinner cooking time in the day that they were to participate in the cooking test. The CO concentration was 
recorded at $10 \mathrm{~s}$ intervals using EL-USB-CO data logger, $\mathrm{PM}_{2.5}$ once per minute using a particles and temperature sensor (PATS) + PM meter after being zeroed following the procedure in PATS + and PICA User Manual_v11 (Berkeley Air Monitoring Group, Berkeley, CA, USA) and $\mathrm{CO}_{2}$ every 1 min using Telaire T7001 Carbon Dioxide and Temperature monitor (Lascar Electronics, Whiteparish, Wiltshire, UK) (Figure 3a). The equipment was hung in the kitchen at one and a half meters above and one meter to the side of the cookstove, which simulated the position of a cook while cooking following the procedure described by [24] (Plate 3b). Measurements were taken for at least 50 min before the cooking started to record the kitchen condition before the cooking exercise begun.

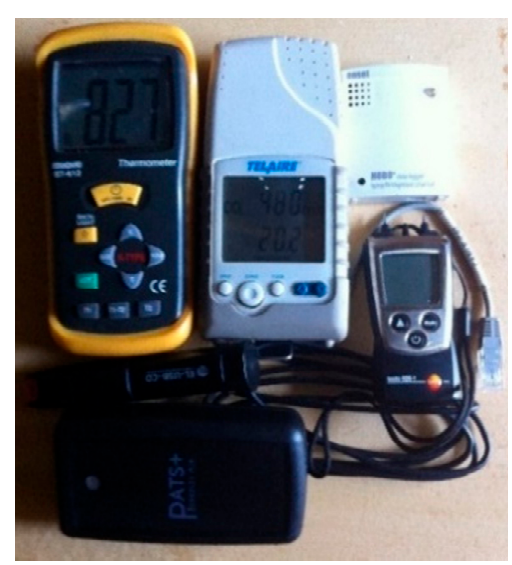

(a)

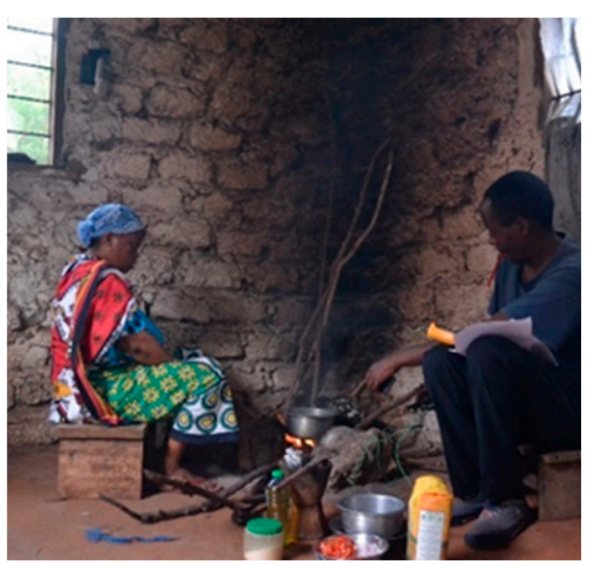

(b)

Figure 3. (a) Equipment used in this study; and (b) emission measurement during normal cooking.

After the cooking process, the equipment was left hanging for at least $50 \mathrm{~min}$ to find out how long the kitchen environment took to normalize. The equipment was then removed and the PATS+ PM meter zeroed, and data downloaded using PICA software. The CO data were downloaded using EasyLog ESB Ver. 7.2.0.0 software (Lascar Electronics) and $\mathrm{CO}_{2}$ using Honest Observer By Onset (HOBO) software.

The results of gases and particles concentrations were compared to the World Health Organization (WHO) air quality guidelines for exposure values to $\mathrm{PM}_{2.5}$ for $24 \mathrm{~h}$ which should not exceed $25 \mu \mathrm{g} / \mathrm{m}^{3}$ (not to be exceeded for more than 3 days per year) [25]. The concentration of $\mathrm{CO}$ was compared to $\mathrm{WHO}$ guidelines of exposure to $\mathrm{CO}$ in $1 \mathrm{~h}$ duration which is $30 \mathrm{ppm}$ (equivalent to $35 \mathrm{mg} / \mathrm{m}^{3}$ using a conversion factor of $1 \mathrm{mg} / \mathrm{m}^{3}=0.873 \mathrm{ppm}$ at $25^{\circ} \mathrm{C}$ ) [26]. Occupational Safety and Health Administration has set the permissible exposure limit (PEL) for $\mathrm{CO}_{2}$ as $5000 \mathrm{ppm}$ average over an $8 \mathrm{~h}$ workday [27]. The flame temperatures were taken using a thermocouple for both stoves at 5, 15 and $25 \mathrm{~min}$ after the stove was well lit which is the average maximum time which maize cob, a potential cooking fuel takes to char. The moisture content of the fuel used was taken using a portable moisture meter from three randomly picked pieces of fuel samples.

\subsection{Kitchen Description}

The kitchen features which included the type of stove, dimensions (length, width, and height), ventilation infrastructures such as windows, doors, chimney, and other spaces left for ventilation purposes were all recorded. The materials used to build the wall and roof of the kitchen were also noted as well as whether the kitchen was a separate structure from the main building or inside the main building. This was achieved through measurements using a measuring tape, observations, and interviews with the household's main cook. For the kitchens with door and windows, the sides to which they open were recorded and whether they were open or closed while cooking which was left to the cook to decide. 


\subsection{Combustion Properties}

Samples of fuel used and the char produced were analyzed for calorific value, percent moisture content, volatile matter, fixed carbon, and ash content at Belab in Stockholm, Sweden to determine their suitability for use as cooking fuel.

The calorific value which is reported in terms of dry weight was analyzed using a bomb calorimeter. The result of the analysis is expressed in MJ/kg and the norm used is SS-EN14918:2010. To determine the volatile matter, the oven-dried sample was incinerated in a muffle furnace for $7 \mathrm{~min}$ at $900{ }^{\circ} \mathrm{C}$ and weighed after cooling. The percentage weight loss of the original sample expressed the volatile matter. The norm used is SS-EN ISO 18123:2015. To measure moisture content, a $5 \mathrm{~g}$ sample was dried in an oven at $103^{\circ} \mathrm{C}$ for $12 \mathrm{~h}$ and expressed as the percentage loss of weight of the original sample. The norm used by Belab Laboratory to determine the moisture content for the samples of this work is: SS-EN ISO 18134-3:2015. The cooled incinerated sample was returned to the muffle furnace at $900{ }^{\circ} \mathrm{C}$ for $15 \mathrm{~h}$ to determine ash content. The weight was expressed as a percentage of the weight of the original sample. The norm used to determine the ash content is SS-EN ISO 18122:2015. For sum of wet sample, moisture content, ash content and volatile matter were subtracted from $100 \%$ to get the value of the fixed carbon (\% as received) while for the sum of the dry sample, ash content and volatile matter were subtracted from $100 \%$ to get the fixed carbon ( $\%$ total solids).

\subsection{Time Spent in Cooking}

The time spent in the cooking process in each household was recorded. This included the time for lighting the stove, the time when the cooking started and ended, time fuel charred, and cooled as well as time spent in the reloading of fuel. This was used to calculate the total time of the cooking process and the total time taken to cook the meal.

\subsection{Data Management and Analysis}

For descriptive statistics, data were analyzed using Microsoft Excel 2013 software for means of the various variables and standard error to show the variances within the samples. The significant differences between the mean values for fuel, time used, flame temperature and concentrations of gases and particles while using gasifier and three-stone open fire were tested using the $t$-test; paired two sample for means (one-tailed). The significance level was set at $p<0.05$.

\section{Results}

\subsection{Fuel Types Used and Flame Temperatures}

Fuel used in this study varied from one household to the other as the households were left to decide on fuel type to use to cook (Table 1). The most common fuels were prunings from casuarina and neem trees used by $32 \%$ and $28 \%$ of households, respectively. The casuarina is used for construction purposes and the pruning and offcuts are used as firewood. Neem is preferred for medicinal purpose and its prunings are used to provide firewood for most of the households.

The average flame temperature of the various fuels used by the household varied from one household to the other. For the gasifier cookstove it was $741.9 \pm 4.6^{\circ} \mathrm{C}$. 
Table 1. Fuels used to cook.

\begin{tabular}{cc}
\hline Fuel Name & Number of Households That Used It \\
\hline Casuarina (Casuarina equisetifolia) & 8 \\
\hline Neem (Azadirachta indica) & 7 \\
\hline Neem and Cashew nut (Anacardium occidentale) & 2 \\
\hline Casuarina and Mangrove (Avicennia marina) & 1 \\
\hline Mkwandzu (Tamarindus indica) & 1 \\
\hline Neem and Casuarina & 1 \\
\hline Neem and Mango (Mangifera indica) & 1 \\
\hline Neem, Mkone (Grewia tembensis) and Mtafunika (mock & 1 \\
\hline orange-Philadelpus coronaries) & 1 \\
\hline Neem and Msungululu (Strophanthus eminii) & 1 \\
\hline Neem and Mbokwe (Annona senegalensis) & 1 \\
\hline Orange (Citrus reticulate) and Mpingo (Dalbergia melanoxylon) & \\
\hline
\end{tabular}

\subsection{Combustion Properties of Fuel and Produced Char}

The average moisture content of the fuels used by the households was $16.7 \pm 0.4 \%$ while from the laboratory it was $8.6 \pm 0.1 \%$. The differences in the two measurements could have been caused by sample preparation through grinding and time between sample collection and analysis which could have caused drying of the samples. The differences in the methods used to measure the moisture content in the field and the laboratory could also cause the difference. The moisture content of the fuel when used by the households and at the laboratory was below the recommended $20 \%$ for firewood before being burned [28]. The energy content of firewood is determined by its moisture content. Firewood which is drier give more energy for cooking or heating as less energy is required to dry the wood [29].

Ash content of the firewood used varied between $1.4 \%$ and $4.5 \%$ of total solids (ts) (Table 2). Casuarina firewood which was used by $32 \%$ of the households, had the lowest ash content among all the fuels types used (Table 2). The combination of orange and mpingo firewood had the highest fixed carbon of $19.8 \%$ (Table 2). A longer burning period is one of the desirable properties of cooking fuel. This can vary among biomass types where biomasses with higher fixed carbon burn for a longer period [30].

Table 2. Combustion properties of fuel used to cook. ts = total solids; $\mathrm{db}=$ dry basis.

\begin{tabular}{|c|c|c|c|c|c|}
\hline Fuel (Biomass) & $\begin{array}{l}\text { Moisture, } \\
105^{\circ} \mathrm{C}(\%)\end{array}$ & $\begin{array}{c}\text { Ash, } 550{ }^{\circ} \mathrm{C} \\
\text { db (\% ts) }\end{array}$ & $\begin{array}{c}\text { Volatile } \\
\text { Matter (\% ts) }\end{array}$ & $\begin{array}{l}\text { C-Fix } \\
(\% \text { ts })\end{array}$ & $\begin{array}{c}\text { Net Cal. Value } \\
\text { Const Press db } \\
(\mathrm{MJ} / \mathrm{kg})\end{array}$ \\
\hline Average Neem $(n=10)$ & $9 \pm 0.2$ & $2.2 \pm 0.3$ & $79.4 \pm 0.6$ & $18.4 \pm 0.4$ & $18.4 \pm 0.1$ \\
\hline Average Casuarina $(n=9)$ & $8.7 \pm 0.1$ & $1.4 \pm 0.1$ & $81.4 \pm 0.3$ & $17.2 \pm 0.3$ & $18.4 \pm 0.1$ \\
\hline Average Cashewnut and Neem $(n=2)$ & 8.3 & 1.5 & 79.4 & 19.2 & 18.3 \\
\hline Neem, Mkone, and Mtafunika & 8.8 & 3.4 & 78.5 & 18.1 & 18.2 \\
\hline Orange and Mpingo & 7.8 & 3.7 & 76.5 & 19.8 & 19.0 \\
\hline Mkwadzu & 8.8 & 4.5 & 79.3 & 16.1 & 17.3 \\
\hline Neem and Mbokwe & 8.8 & 2.8 & 78.5 & 18.8 & 18.2 \\
\hline Neem and Mtsungululu & 8.5 & 1.9 & 79.5 & 18.6 & 18.5 \\
\hline Neem and Casuarina & 8.7 & 2 & 79.8 & 18.3 & 18.4 \\
\hline Casuarina and Mangrove & 8.9 & 1.4 & 81.3 & 17.3 & 18.6 \\
\hline Average Mango and Neem $(n=2)$ & 8.2 & 1.6 & 80.9 & 17.6 & 18.5 \\
\hline
\end{tabular}

Fuel samples used with three-stone open fire and gasifier were collected and analyzed separately (30 samples in total). On a dry basis, neem firewood had higher ash content, lower volatile matter and 
lower fixed carbon than casuarina and $t$-test showed a significant difference in the biomasses from the two species ( $p=0.012,0.008,0.021$ respectively). Orange and mpingo firewood had the highest net calorific value of $19.1 \mathrm{MJ} / \mathrm{kg}$ (Table 2). The energy content per unit mass and fuel type define its calorific value. Fuels with high calorific value are better for cooking as they release more heat [31].

The char produced can be used as cooking fuel as well. For the households who reloaded fuel, char from both the first and second charring were collected separately and analyzed (31 samples in total). Char from a mix of neem and casuarina had the highest calorific value while that from casuarina had the highest fixed carbon implying that they are of good fuel quality (Table 3). Char samples from the commonly used fuels neem and casuarina had a significant difference in ash content $(p=0.035)$ which was higher in neem than casuarina implying that the latter had better quality char. The calorific value of char after gasification was $71 \%$ higher than in feedstock on average while the volatile matter was $85.6 \%$ lower than in feedstock. This agrees with the observation by Pennise et al. [32] which reported that wood carbonizing gives charcoal with higher energy density than air-dried firewood. If the char produced is used as fuel, the concentrations of $\mathrm{CO}$ during cooking would increase and that of $\mathrm{PM}_{2.5}$ decrease compared to original fuel [33]. In their study the authors also reported that char produced from gasifier had good quality for cooking which compared well with conventional charcoal.

Table 3. Combustion properties of produced char.

\begin{tabular}{|c|c|c|c|c|c|}
\hline Fuel (Char) & $\begin{array}{l}\text { Moisture, } \\
105^{\circ} \mathrm{C}(\%)\end{array}$ & $\begin{array}{c}\text { Ash, } 550{ }^{\circ} \mathrm{C} \\
\text { db (\% ts) }\end{array}$ & $\begin{array}{c}\text { Volatile } \\
\text { Matter (\% ts) }\end{array}$ & $\begin{array}{l}\text { C-Fix } \\
(\% \text { ts })\end{array}$ & $\begin{array}{c}\text { Net Cal. Value } \\
\text { Const Press db } \\
(\mathrm{MJ} / \mathrm{kg})\end{array}$ \\
\hline Average Neem $(n=10)$ & $8 \pm 0.2$ & $4.8 \pm 0.3$ & $10.4 \pm 0.5$ & $84.8 \pm 0.6$ & $32 \pm 0.1$ \\
\hline Average Casuarina $(n=9)$ & $7.5 \pm 0.3$ & 3.4 & $10.9 \pm 0.7$ & 87.5 & $32.4 \pm 0.2$ \\
\hline Average Cashewnut and neem $(n=4)$ & $8.2 \pm 0.7$ & $5.2 \pm 0.6$ & $11 \pm 1.5$ & $83.8 \pm 1.6$ & $31.3 \pm 0.4$ \\
\hline Neem and Casuarina & 6 & 4.7 & 12.2 & 83.1 & 32.5 \\
\hline Mango and Neem & 7 & 4.9 & 10.9 & 84.2 & 32.3 \\
\hline Orange and Mpingo & 7.6 & 13.1 & 14.8 & 72.1 & 29.0 \\
\hline Neem and Mtsungululu & 8.7 & 6.7 & 9.9 & 83.4 & 31.2 \\
\hline Mkwandzu & 6.9 & 10.6 & 13.2 & 76.2 & 30.0 \\
\hline Neem and Mbokwe & 7.9 & 6.6 & 11.3 & 82.1 & 31.2 \\
\hline Casuarina and Mangrove & 8.4 & 4.6 & 9.6 & 85.9 & 32.0 \\
\hline Neem, Mkone, and Mtafunika & 8.1 & 6.5 & 10 & 83.5 & 31.4 \\
\hline
\end{tabular}

The average volatile matter and moisture content of the produced char was below the recommended $30 \%$ and $10 \%$ respectively [34]. However, the ash content was higher than the recommended $3 \%$ for good lamp charcoal [34].

\subsection{Respondent Kitchen Description}

$60 \%$ of the kitchens were separate structures from the main building while $40 \%$ were within the main building. Kitchens for $28 \%$ of the households had a physical door which closed and opened, $56 \%$ had a door space without a physical door and $16 \%$ had open front walls. All $28 \%$ of the households with a door on their kitchens kept them open during cooking exercise. $68 \%$ of the kitchens had no physical window(s) but had ventilation from some of the walls that were left open or built halfway. $32 \%$ of the kitchens had window spaces which were either left open or covered with a mesh. Generally, the kitchens had good ventilation due to the presence of the windows, doors, and open sections of some of the walls.

\subsection{Time Usage in Cooking with Gasifier and Three-Stone Open Fire}

The gasifier took significantly $(p=0.04)$ more time to light (which means time to ignite fuel to time when it is well lit and time to move it back to the kitchen and start cooking) than three-stone open fire (Figure 1). This could be attributed to the nature of lighting the gasifier as it is lit from the top of the fuel unlike three-stone open fire which is lit from below the fuel. Generally, the time taken to light the fuel with the gasifier could be attributed to the moisture content of the fuel, the lighting material used, 
the arrangement of fuel in the canister and blowing effort spent on lighting it. Improper arrangement of fuel especially packing more fuel leaving no air spaces caused the stove to take longer to light. The time taken to light fuel load two was shorter than that of fuel load one as the cooks were halfway with their cooking and feared that their food might go flat hence they aided the fuel to light faster by blowing with a pipe or fanning it with a piece of plastic/pot lid.

Differences in time spent by the different households in cooking with the gasifier was mainly due to the differences in types of meals cooked and fuels used. On average cooking (the time when food was on the fire) took $44 \pm 9 \mathrm{~min}$ on the gasifier irrespective of changeover or not and $45 \pm 13 \mathrm{~min}$ with three-stone open fire (Figure 4). There was a significant difference in the time of the cooking process with the gasifier and three-stone open fire $(p=0.001)$. Reloading and relighting when fuel chars before the food gets ready lengthened cooking process using the gasifier.

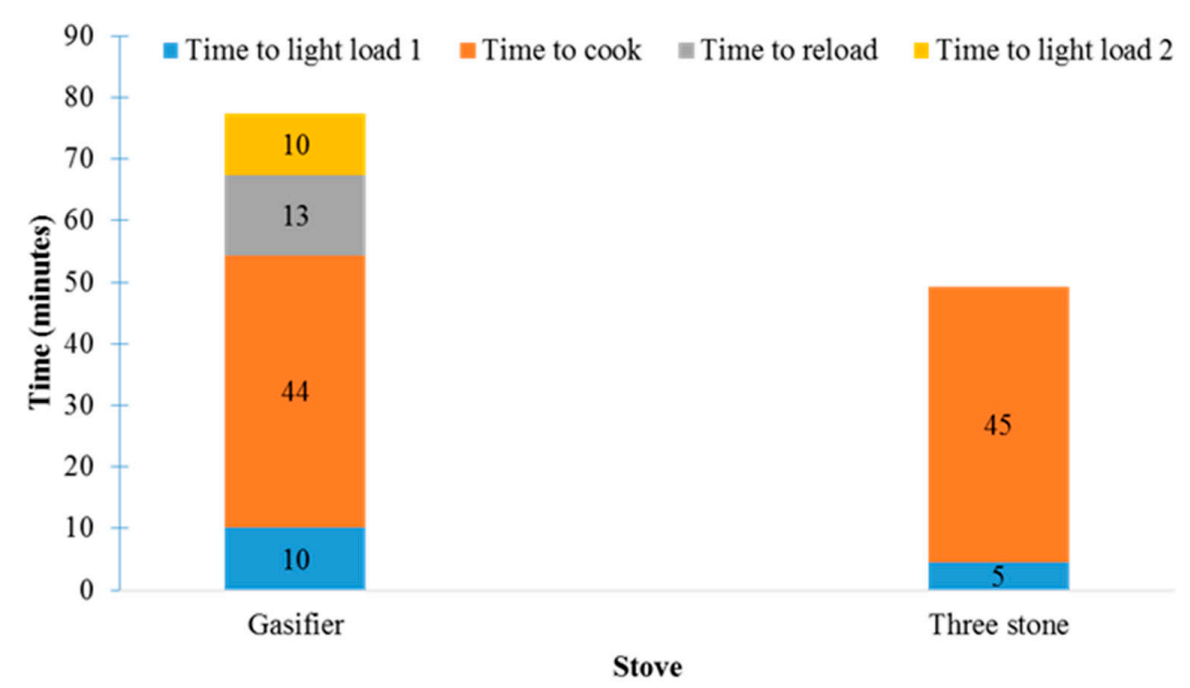

Figure 4. Time spent in cooking with the gasifier and three-stone open fire.

For the households that did not have a changeover, the average cooking process took $56 \pm 3 \mathrm{~min}$. For the households that had a changeover, the cooking process including relighting and reloading took $100 \pm 10$ min (Figure 5).

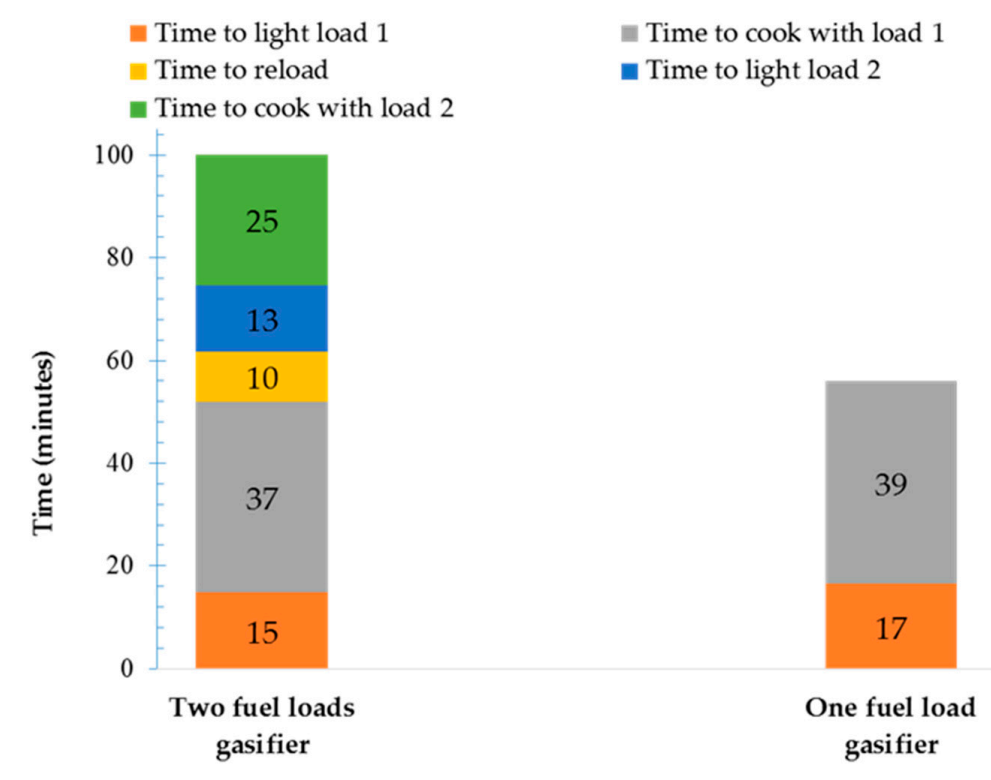

Figure 5. Average time spent cooking with the gasifier with and without fuel refilling. 
The difference in the time spent in the cooking process with the two stoves could be attributed to the time taken to light the fuel and need for the changeover for the gasifier especially when fuel charred before the food got ready. A study by [17] reported cooking with a larger galvanized gasifier stove by rural households in Kenya as relatively faster than three-stone open fire. The difference could be attributed to the larger size of the galvanized gasifier canister $(22 \mathrm{~cm}$ high) and hence it could hold more fuel than current stove canister which is $19 \mathrm{~cm}$ high. Even though the gasifier uses slightly more time to light and cook food, it uses less fuel, which translates into saving on time spent in firewood collection, which could be a benefit for the women. According to [22], women in this area spend $3 \mathrm{~h}$ and $1 \mathrm{~h} 40 \mathrm{~min}$ to collect a head load of firewood from the forest and on-farm, respectively. However, there could be tradeoffs in the two forms of time saving.

\subsection{Activities with the Gasifier That Could Increase Time Usage}

Cooking with the gasifier has additional activities which include chopping wood into small pieces, arranging fuel in the canister, harvesting and cooling char, reloading and changing over when fuel chars before the food get ready. These challenges were identified by the cooks as factors that might affect the adoption of the new stove [23]. Although it only happened in $24 \%$ of the households, changeover significantly lengthened the time spent on the cooking process an issue that was identified as a factor that might influence the adoption of the new stove [23]. Further need for change over affect choice of the type of food cooked with the gasifier households preferring those that take a shorter time to get ready. Failure of the improved stoves to meet the user's needs can result in their abandonment. For instance, a TLUD gasifier stove was abandoned one month after use in Tanzania for not meeting the user needs [35].

\subsection{Cooking Responsibilities}

Cooking is mainly the responsibility of female heads as female head, male head, daughter and son were the cooks in $73,13,10$ and $3 \%$ of the households, respectively. For $13 \%$ of the households where male head cooked, 2 household heads had separated with their spouse and hence they were cooking for themselves, while for one, the wife was in the hospital but often helps her with cooking even when she is at home.

\subsection{Fuel Preparation, Usage, and Produced Char by Gasifier}

The firewood used was prepared by the female head, male head, daughter and grandson in 50 , 40,7 and $3 \%$ of the households, respectively. The males found firewood preparation easier than the females. Firewood for $80 \%$ of the households was prepared using a machete, $17 \%$ using a machete and an axe and 3\% using a saw. Males prepared firewood using saws and machetes while females used machetes and axes. About $76 \%$ of the households used one fuel load to cook a meal with the gasifier which weighed $1009 \pm 34 \mathrm{~g}$ on average. $24 \%$ of the households needed to reload the gasifier with fuel for the food to get ready and the average total fuel used was $1748 \pm 146 \mathrm{~g}$. Irrespective of whether there was a changeover or not, the total average fuel used with the gasifier was $1208 \pm 74 \mathrm{~g}$ and the average weight of one canister of fuel was $998.7 \mathrm{~g}$. Out of the $76 \%$ of the households who used one fuel load to cook the dinner, food got ready in $84 \%$ of the households before the fuel charred and there was energy for an extra $13.5 \mathrm{~min}$ on average that could be used for other purposes. In $24 \%$ of the households that used two fuel loads, food got ready before the second fuel load charred in $83 \%$ of the households and it burned for an extra 13.4 min on average.

When the flame died, charring was complete, and the char was harvested before it could burn into ashes. The households that used one fuel load produced char ranging between 73 to $226 \mathrm{~g}$ and $173 \pm 6 \mathrm{~g}$ on average. Produced char from the households that used two fuel loads ranged between 170 and $320 \mathrm{~g}$ with an average of $284 \pm 33 \mathrm{~g}$. The total average char produced from the gasifier by all the households was $200 \pm 13 \mathrm{~g}$. The differences in the amount of char produced could be attributed to the differences in timing on when to harvest the char, the variations in the characteristics of different fuels 
used and amounts of firewood loaded into the fuel canister. If the cook did not time well to harvest the char immediately after charring, it continued to burn turning into ash hence reducing the amount of char that was harvested.

Casuarina fuel stock to char conversion for the eight samples (considering only the 1st charring in instances where there was reloading) was $16.4 \pm 0.5$ on average while for neem it was $16.1 \pm 0.6$. The difference could be attributed to the higher fixed carbon in casuarina. The conversion of all the fuels stock to char by weight was $16.6 \pm 0.3 \%$ on average. This was less than what was reported by [17] where conversion efficiency was $20 \%$. This difference in results could be attributed to the larger galvanized gasifier fuel canister and fuel types.

From the $98 \%$ of the households who harvested char from the gasifier, $23 \%$ and $4 \%$ of the households used it to cook and iron their clothes respectively [23]. The char produced from the gasifier was also used as biochar by being applied to the maize plots by households at Kwale. This resulted in increase in maize grain yields from $0.9 \mathrm{Mg} \mathrm{ha}^{-1}$ in the control plot to $4.4 \mathrm{Mg}$ on average in the first season [36]. In another site in Embu where farmers used biochar from a similar gasifier on kale, the yield increased by $33 \%$ with the addition of biochar [36].

\subsection{Concentrations of $\mathrm{CO}, \mathrm{CO}_{2}$, and $\mathrm{PM}_{2.5}$ in the Kitchen When Cooking}

The concentration of the pollutants monitored during the test period varied among the households as shown in Table 4. The period considered was from when the stove was well lit and moved into the kitchen until the end of charring for gasifier, and from when the fuel was well lit until the firewood was withdrawn and the fire put off for three-stone open fire. These variations could be due to a combination of factors that included kitchen size and ventilation, fuel characteristics, and stove handling. From one of the households that used casuarina firewood with gasifier, $\mathrm{PM}_{2.5}$ value was dropped due to failure with the equipment and hence not included in the discussion.

Table 4. Concentration levels of $\mathrm{CO}, \mathrm{CO}_{2}$, and $\mathrm{PM}_{2.5}$ and fuel used in cooking with gasifier.

\begin{tabular}{ccccc}
\hline No. of Hhs & Fuel Type & $\mathbf{P M}_{\mathbf{2 . 5}}\left(\boldsymbol{\mu g} / \mathbf{m}^{\mathbf{3}}\right)$ & $\mathbf{C O}(\mathbf{p p m})$ & $\mathbf{C O}_{\mathbf{2}}(\mathbf{p p m})$ \\
\hline 8 & Casuarina & $124 \pm 37$ & $10.1 \pm 2.6$ & $690 \pm 21$ \\
7 & Neem & $120 \pm 60$ & $4.9 \pm 2.5$ & $641 \pm 21$ \\
2 & Neem and Cashew nut & 83 & 3.9 & 643 \\
1 & Neem and Masuarina & 45 & 4.1 & 553 \\
$1 *$ & Orange and Mpingo & 4708 & 47.7 & 1883 \\
1 & Casuarina and Mangrove & 43 & 3.6 & 621 \\
1 & Neem and Mango & 124 & 0.4 & 607 \\
1 & Neem, Mkone, and Mtafunika & 37 & 0.2 & 604 \\
1 & Neem and Mtsungululu & 46 & 6.6 & 712 \\
1 & Neem and Mbokwe & 28 & 0.5 & 608 \\
1 & Mkwandzu & 75 & 2.4 & 648 \\
\hline \multicolumn{7}{c}{ Average with outlier } & $\mathbf{4 9 4}$ & $\mathbf{7 . 7}$ & $\mathbf{7 4 6}$ \\
\hline
\end{tabular}

Orange and mpingo fuel combination had the highest concentration of all pollutants monitored during the cooking with gasifier (Table 4 ) and was treated as an outlier. This combination was used only by one household whose kitchen was observed to be small in size and with very limited ventilation which is probably the cause of higher concentrations. The $\mathrm{CO}$ concentrations from the gasifier without the outlier were below the critical limits of $30 \mathrm{ppm}$ allowed for human exposure for $1 \mathrm{~h}$ in all the households [26]. $\mathrm{CO}_{2}$ was also below the permissible exposure limit of $5000 \mathrm{ppm}$ averaged over an $8 \mathrm{~h}$ workday without the outlier in all the households [27]. However, without the outlier $\mathrm{PM}_{2.5}$ was above the $24 \mathrm{~h}$ level exposure limit of $25 \mu \mathrm{g} / \mathrm{m}^{3}$ [25] in 23 households and below in one household, 
and exceeded the threshold by $189 \%$ on average. The authors did not find any short-term exposure limits to compare to and hence $24 \mathrm{~h}$ level exposure limit was used. However, it should be noted that cookstoves do not give $24 \mathrm{~h}$ exposure to this concentration.

\subsection{Comparison between Cooking with a Gasifier and Three-Stone Open Fire}

\subsubsection{Food Cooked and the Fuel Used with the Gasifier and Three-Stone Open Fire}

Households were left to cook food of their choice (Table 5) and each household cooked the same food and amount with gasifier and three-stone open fire for comparison. Cooking with the gasifier consumed less fuel compared to cooking with three-stone open fire and there was a significant difference in the fuel used by the two stoves $(p=0.01)$. Fuel savings was $32 \%$ by weight if the char produced is considered to be additional fuel and $18 \%$ if char produced is not considered to be fuel (Table 5). This agrees with finds by Njenga et al. [17], where using TLUD galvanized gasifier by households in rural Kenya, saved $40 \%$ of fuel. This implies that adopting biochar-producing gasifier cookstove will save fuel. This can result in reduced need to collect firewood if the household switched to using the gasifier. Consequently, this will minimize the forest degradation associated with firewood collection for household use which mainly involves the removal of dead wood hence depriving forest organic matter [37]. Women will also save on the amount of time spent on firewood collection where for instance after switching to improved cookstove from three-stone fire, women in Dadaab camp were saving $16 \mathrm{~h}$ per week [38] which they could spend on income generation, self-empowerment, or the activities of their choice and this contributes to gender equity.

Table 5. Food cooked and fuel used with the gasifier and three-stone (3-stone) open fire. Avrg = Average; Fuel + char $=$ Fuel used during cooking and charring period including char; Fuel-char $=$ Fuel used during cooking and charring period minus char.

\begin{tabular}{|c|c|c|c|c|c|c|c|c|}
\hline $\begin{array}{l}\text { Hh } \\
\text { No. }\end{array}$ & $\begin{array}{c}\text { Fuel + } \\
\text { Char (g) }\end{array}$ & $\begin{array}{c}\text { Fuel-Char } \\
\text { (g) }\end{array}$ & $\begin{array}{c}\text { Char } \\
\text { Produced (g) }\end{array}$ & $\%$ Char & $\begin{array}{l}\text { Fuel Used } \\
\text { 3-stone (g) }\end{array}$ & $\begin{array}{l}\text { Fuel } \\
\text { Type }\end{array}$ & Food Cooked & $\begin{array}{c}\text { Food } \\
\text { Cooked (g) }\end{array}$ \\
\hline 1 & 1119 & 926 & 193 & 17.3 & 1528 & Casuarina & $\begin{array}{c}\text { Ugali } \\
\text { Kale (Brassica } \\
\text { oleracea })\end{array}$ & $\begin{array}{c}3388 \\
670\end{array}$ \\
\hline 2 & 1944 & 1621 & 323 & 16.6 & 2019 & Neem & $\begin{array}{c}\text { Chapati } \\
\text { Black Tea } \\
\text { Green peas } \\
\text { (Pisum sativum })\end{array}$ & $\begin{array}{l}1148 \\
1860 \\
1813\end{array}$ \\
\hline 3 & 1317 & 1147 & 170 & 12.9 & 1510 & Neem & $\begin{array}{c}\text { Potatoes } \\
\text { (Solanum } \\
\text { tuberosum) stew } \\
\text { Black Tea }\end{array}$ & $\begin{array}{l}2072 \\
1201\end{array}$ \\
\hline 4 & 878 & 718 & 160 & 18.2 & 1080 & Neem & $\begin{array}{l}\text { Ugali } \\
\text { Coconut milk } \\
\text { and fish stew }\end{array}$ & $\begin{array}{l}1745 \\
538\end{array}$ \\
\hline 5 & 767 & 623 & 144 & 18.77 & 1240 & $\begin{array}{l}\text { Neem + } \\
\text { Mango }\end{array}$ & $\begin{array}{l}\text { Ugali } \\
\text { Fish }\end{array}$ & $\begin{array}{c}2715 \\
816\end{array}$ \\
\hline Avrg & $1205 \pm 208$ & $1007 \pm 178$ & $198 \pm 32$ & $16.8 \pm 1$ & $1475 \pm 16$ & - & - & - \\
\hline
\end{tabular}

3.9.2. Concentrations of $\mathrm{CO}, \mathrm{CO}_{2}$, and $\mathrm{PM}_{2.5}$ When Cooking with Gasifier and Three-Stone Open Fire

Compared to three-stone open fire, the concentrations of $\mathrm{CO}, \mathrm{CO}_{2}$, and $\mathrm{PM}_{2.5}$ were $57 \%, 41 \%$ and $79 \%$ lower when cooking with gasifier respectively (Table 6). The concentrations recorded during the tests are shown in Table 4 above. 
Table 6. Concentrations during cooking with gasifier and 3-stone open fire.

\begin{tabular}{ccccccccc}
\hline \multirow{2}{*}{ Hh No. } & \multicolumn{2}{c}{$\mathbf{P M}_{\mathbf{2 . 5}}\left(\boldsymbol{\mu g} / \mathbf{m}^{\mathbf{3}}\right)$} & \multicolumn{2}{c}{$\mathbf{C O}(\mathbf{p p m})$} & \multicolumn{2}{c}{$\mathbf{C O}_{\mathbf{2}}(\mathbf{p p m})$} & \multicolumn{2}{c}{ Time Taken to Cook (Min) } \\
\cline { 2 - 8 } & Gasifier & 3-Stone & Gasifier & 3-Stone & Gasifier & 3-Stone & Gasifier & 3-Stone \\
\hline 1 & 225 & 421 & 3.0 & 6.1 & 667 & 2499 & 48 & 35 \\
2 & 105 & 120 & 4.3 & 9.9 & 611 & 713 & 104 & 57 \\
3 & 459 & 2462 & 18.7 & 21.3 & 735 & 818 & 54 & 45 \\
4 & 24 & 605 & 3.9 & 3.8 & 616 & 622 & 26 & 20 \\
5 & 124 & 761 & 0.4 & 28.6 & 607 & 801 & 35 & 23 \\
\hline Avrg & $\mathbf{1 8 7} \pm \mathbf{7 5}$ & $\mathbf{8 7 4} \pm \mathbf{4 1 1}$ & $\mathbf{6} \pm \mathbf{3}$ & $\mathbf{1 4} \pm \mathbf{5}$ & $\mathbf{6 4 7} \pm \mathbf{2 5}$ & $\mathbf{1 0 9 1} \pm \mathbf{3 5 3}$ & $\mathbf{5 3 . 4} \pm \mathbf{1 3 . 6}$ & $\mathbf{3 6} \pm \mathbf{6 . 9}$ \\
\hline
\end{tabular}

These results are similar to those reported by [17] where use of galvanized gasifier which functions like the gasifier used in this study reduced concentrations of $\mathrm{PM}_{2.5}$ by $90 \%$ and CO by $45 \%$ among rural households in Kenya. Also reference [39] reported a reduction in indoor air pollution due to the use of improved cookstoves. In their study in the mid-hill region of Nepal, they found out that $\mathrm{PM}_{2.5}$ concentration was more than halved when households switched from traditional cookstove to an improved stove $\left(2070 \mathrm{mg} / \mathrm{m}^{3}\right.$ to $\left.760 \mathrm{mg} / \mathrm{m}^{3}\right)$ while CO concentration was reduced by $60 \%(21.5 \mathrm{ppm}$ to $8.6 \mathrm{ppm}$ ). The $\mathrm{PM}_{2.5}$ is the principal exposure of particular concern from burning biomass as it is associated with illnesses such as pneumonia, cardiovascular disease, stroke and lung cancer [40-42].

As a result, the adoption of the efficient stove with lower emission reduces exposure to indoor air pollutants. Also, the gasifier reduces the release of pollutants into the environment some of which are GHG, and this could potentially have a cumulative effect of reducing global warming potential hence mitigating climate change. This is so because $25 \%$ of global emission of black carbon a major component of particulate matter is from household combustion [43].

The gasifier was lit outside as is the common practice in sub-Saharan Africa (SSA) with portable stoves, and only returned into the kitchen when the fuel is well lit and had stopped smoking. This means that the initial phase of lighting biomass which produces a lot of smoke takes place outside the kitchen, resulting in reduced concentrations of indoor air pollutants in the kitchen [44]. These results confirm the findings of previous studies that showed improvement in indoor air quality when improved biomass cookstoves were used compared to use of traditional open fires [17,37,45].

The biomass in the fuel canister of the gasifier is gasified to produce gases which are burned at high temperatures in the combustion chamber to generate heat that is used to cook [16]. The flame temperatures of the gasifier varied from household to household due to the varying fuel types used by the households. The average flame temperature of the gasifier and three-stone open fire taken after 25 min into cooking was $738.1 \pm 6.3^{\circ} \mathrm{C}$ and $648.2 \pm 6.3^{\circ} \mathrm{C}$ respectively (Table 7). There was a significant difference in the flame temperatures of the two stoves $(p=0.0004)$.

Table 7. Flame temperature of the gasifier and three-stone open fire.

\begin{tabular}{ccc}
\hline $\begin{array}{c}\text { Time after Fuel Was Well Lit } \\
\text { (Min) }\end{array}$ & $\begin{array}{c}\text { Gasifier Flame Temperature } \\
\left({ }^{\circ} \mathbf{C}\right)\end{array}$ & $\begin{array}{c}\text { Three-Stone Flame Temperature } \\
\left({ }^{\circ} \mathbf{C}\right)\end{array}$ \\
\hline 5 & 710.4 & 645.6 \\
15 & 741 & 641.8 \\
25 & 763 & 657.2 \\
\hline Avrg & $\mathbf{7 3 8 . 1 \pm 6 . 3}$ & $\mathbf{6 4 8 . 2} \pm 6.3$ \\
\hline
\end{tabular}

When using the same stove, the pollutants concentrations in the kitchens varied and this could be attributed to varying user behavior, airflow, and changeover. The indoor air pollution can be associated with cooking as the concentrations of $\mathrm{CO}, \mathrm{CO}_{2}$, and $\mathrm{PM}_{2.5}$ were low before and after cooking as illustrated in Figures 3-5 from one of the households who cooked with both stoves and reloaded fuel when cooking with the gasifier. Before the start of cooking, the concentration of $\mathrm{CO}$ was low and almost constant but varied through the cooking period and declined to about zero again after the end 
of cooking as shown in the graph in Figure 6 below. The changeover occurred in the middle of cooking where the concentration went back to almost zero.

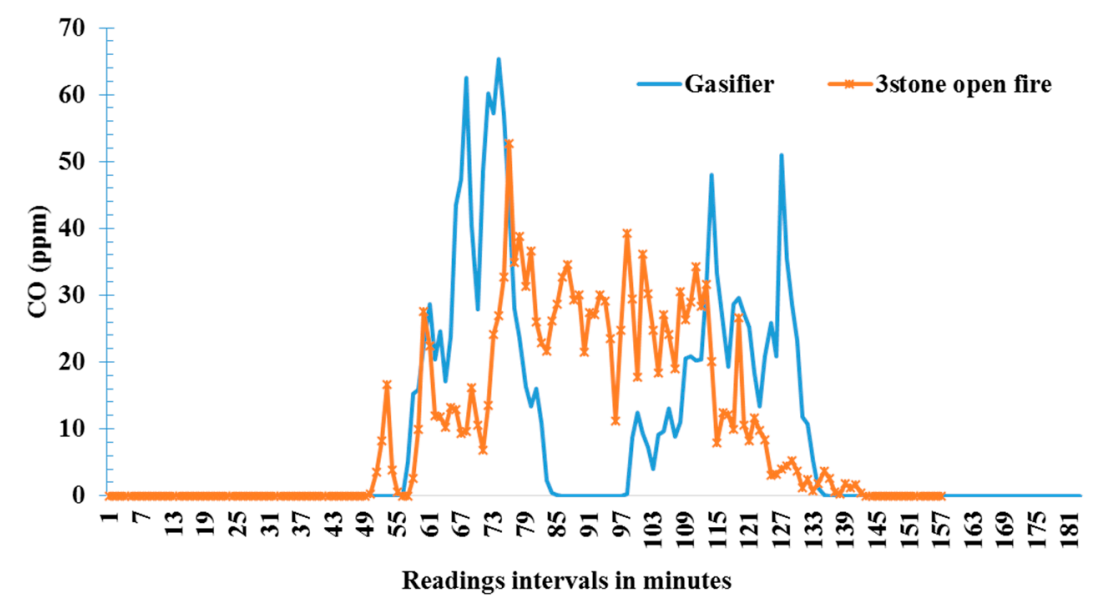

Figure 6. Concentration of $\mathrm{CO}$ in the kitchen before, during, and after cooking with three-stone open fire and gasifier in the household No. 14.

The concentrations of $\mathrm{CO}_{2}$ were constant before the start of cooking and increased when cooking started. After cooking, the concentration reduced to about the same amount as before cooking as shown in Figure 7.

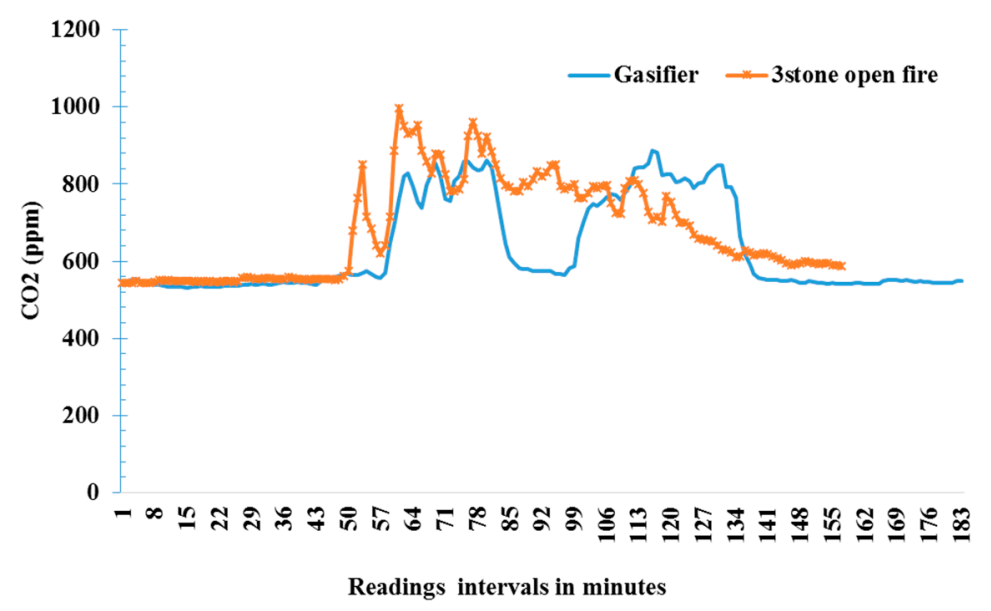

Figure 7. Concentration of $\mathrm{CO}_{2}$ before, during and after the end of the cooking when using gasifier and three-stone open fire in the household No. 14.

Before the start of cooking exercise, the concentration of $\mathrm{PM}_{2.5}$ was low at $10 \mu \mathrm{g} / \mathrm{m}^{3}$ for both gasifier and three-stone open. The concentration increased during cooking with sparks from three-stone open fire that might have been caused by pushing firewood hence stirring of the particles in the ash and burning fuel. After cooking, the concentration reduced again to 10 and $14 \mu \mathrm{g} / \mathrm{m}^{3}$ in gasifier and three-stone open fire respectively as shown in Figure 8 below.

Pollutants from household combustion are mainly released into the air during cooking and as such to reduce the environmental impacts associated with biomass burning, stoves which are cleaner and energy efficient needs to be promoted among the rural households. The gasifier has better energy use efficiency and lower concentrations of indoor air pollutants than three-stone open fire. However, to maximize on the energy saving and potential health impacts of the improved stoves, these stoves must be consistently used by the households hence replacing the traditional stove [46]. 


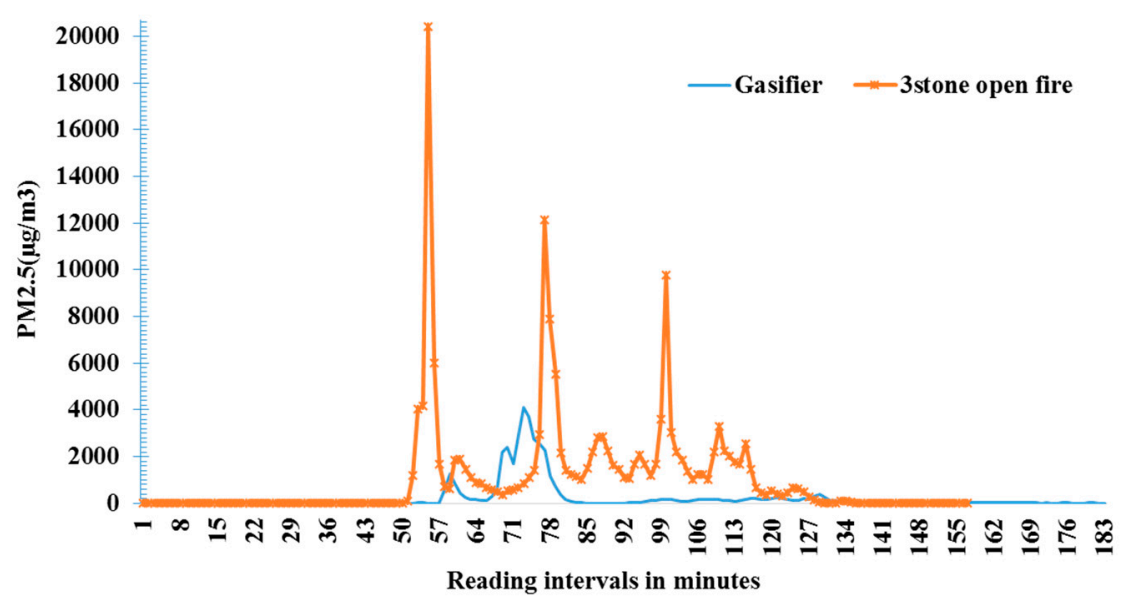

Figure 8. Concentrations of $\mathrm{PM}_{2.5}$ in the kitchen before, during, and after cooking with gasifier and three-stone open fire in in the household No. 14.

\subsection{Climate Impact of the Gasifier}

Using a gasifier cookstove, the impact on the environment could be reduced. This is mainly because the gasifier uses less fuel as was observed in this study and confirms results from the previous study by [17]. This reduces the need to collect fuel and/or even need to cut down trees for firewood, hence reducing environmental degradation. The gasifier produces lower pollutants concentrations in the kitchen than three-stone open fire and its use is beneficial to the environment as lower GHG and particles are released. Moreover, if biochar is used as a soil amendment, carbon is sequestered for decades or centuries [46]. In the study by [47], reported biochar system to save $89 \%$ of the climate change impact caused by the traditional system with the extended pollutants set and a time frame of 20-years, GWP20.

\subsection{Benefits and Limitations of Gasifier Cookstoves}

From the users perceptive, the gasifier produced less smoke, saved fuel and produced char as a by-product $[17,23]$. This study quantified these benefits as discussed earlier. Furthermore, this study found out that lighting of the gasifier took longer compared to three-stone open fire and this had been previously identified by the users as one of the challenges faced with the use of gasifier stove [23].

\subsection{Variability among the Households}

One reason for the variability observed across households in energy use efficiency and pollutants concentrations in the kitchen during cooking period though not statistically tested could be the different fuel types (single fuel or fuel mixes) used by the households to cook and the varying conditions of the fuels at the time of use. The need for fuel reloading, which occurred in $24 \%$ of the households, could also lead to variation in pollutant concentrations since higher amount of fuels is burned for foods which takes longer to cook.

\section{Conclusions}

Households used a variety of locally available wood types as fuel. Compared to three-stone open fire, gasifier used less fuel to cook food of the household choice by $32 \%$ and $18 \%$ when char produced is considered to be fuel or put into other uses respectively. The gasifier produced char as a by-product which the households can use as fuel for another cooking further reducing energy poverty. In the gasifier, $16.6 \%$ of the fuel used to cook remained in char. In addition, the $\mathrm{CO}, \mathrm{CO}_{2}$, and $\mathrm{PM}_{2.5}$ concentrations were lower when cooking with the gasifier than three-stone open fire by $57 \%, 41 \%$ and $79 \%$ respectively. The gasifier was found to be an efficient and cleaner cooking system that produces char as a by-product which could be used for another cooking hence its adoption could 
enable households to become more cooking energy secure. However, the gasifier was found to take relatively more time to light and cook the meal than three-stone open fire. This happened when there was a need for fuel reloading when the fuel charred before the food got ready. Although the gasifier takes a bit more time to light and cook, there was a substantial reduction in firewood used. This results in a reduction in the time and effort spent collecting firewood on foot, which represents an important saving of women's time, overall. There can be tradeoffs between the time spent to cook and to collect firewood since the cooking time is a period that can also be used for other food preparation tasks in parallel, whereas fuel collection time is time away from home.

\section{Recommendations}

To enhance the performance of the gasifier, the fuel used should have low moisture content to reduce the amount of heat which goes into the drying of fuel while burning. To further save the fuel, the cook should quench the burning fuel in the canister when cooking is completed before the fuel charred and use it another time. The recommendation of issuing a second canister made by the users should be implemented. This would allow the cooks to cook all food types with the gasifier and harvest char which they could use for another cooking or as biochar. The time spent between the changeovers and relighting while using one canister will also be reduced. The gasifier cookstove should be promoted among rural households as it saves fuel, reduces indoor air pollutants, produces char which could be used as fuel or soil amendment.

Author Contributions: Conceptualization, J.K.G., C.S., R.M., J.M. and M.N.; Data curation, J.K.G.; Formal analysis, J.K.G.; Funding acquisition, C.S. and M.N.; Investigation, J.K.G., C.S., R.M., J.M. and M.N.; Methodology, J.K.G., C.S., R.M., J.M. and M.N.; Project administration, J.K.G., C.S. and M.N.; Resources, C.S. and M.N.; Supervision, J.K.G., C.S., R.M., J.M. and M.N.; Validation, J.K.G., C.S., R.M., J.M. and M.N.; Visualization, J.K.G., C.S., R.M., J.M. and M.N.; Writing—original draft, J.K.G.; Writing—review \& editing, J.K.G., C.S., R.M., J.M. and M.N.

Funding: The research was funded by the Swedish Research Council, Grant No. 2015 03180, and the Swedish Research Council for Environment, Agricultural Sciences and Spatial Planning, Grant No. 924-2015-1112.

Acknowledgments: The authors are grateful to the World Agroforestry (ICRAF) for offering a platform for training a Ph.D. in collaboration with Wangari Maathai Institute for Peace and Environmental Studies, University of Nairobi. The co-learning established between the Kenya Industrial Research and Development Institute (KIRDI), the manufacturers of the GASTOV, and the research team is gratefully acknowledged. The research objectives would not have been achieved without the participation of the households at Kwale, as well as all the members of the research team. The authors appreciate the additional staff time support for Mary Njenga by World Agroforestry Centre (ICRAF) and the CGIAR Research Program on Water Land and Ecosystem flagship on sustaining rural-urban linkages and the travel support to Kenya offered to Ruth Mendum at the Office of International Programs, College of Agricultural Sciences, Pennsylvania State University.

Conflicts of Interest: The authors declare no conflict of interest.

\section{References}

1. World Health Organization (WHO). Ambient (Outdoor) Air Quality and Health; WHO: Geneva, Switzerland, 2016. Available online: http://www.who.int/mediacentre/factsheets/fs313/en/ (accessed on 30 January 2019).

2. Ministry of Energy (MoE), Government of Kenya. Study on Kenya's Energy Demand, Supply and Policy Strategy for Households, Small-Scale Industries and Service Establishments; Final Report; KAMFOR Company Ltd.: Kampala, Uganda, 2002.

3. Food and Agriculture Organization of the United Nations (FAO). The Charcoal Transition: Greening the Charcoal Value Chain to Mitigate Climate Change and Improve Local Livelihoods; van Dam, J., Ed.; FAO: Rome Italy, 2017.

4. Adria, O.; Bethge, J. What Users Can Save with Energy-Efficient Cooking Stoves and Ovens; Wuppertal Institute for Climate, Environment and Energy: Wuppertal, Germany, 2013.

5. Bonjour, S.; Adair-Rohani, H.; Wolf, J.; Bruce, N.G.; Mehta, S.; Prüss-Ustün, A.; Lahiff, M.; Rehfuess, E.A.; Mishra, V.; Smith, K.R. Solid fuel use for household cooking: Country and regional estimates for 1980-2010. Environ. Health Perspect. 2013, 121, 784-790. [CrossRef] [PubMed]

6. Jetter, J.J.; Kariher, P. Solid-fuel household cook stoves: Characterization of performance and emissions. Biomass Bioenergy 2009, 33, 294-305. [CrossRef] 
7. WHO. WHO Indoor Air Quality Guidelines: Household Fuel Combustion. 2014. Available online: http://www.who.int/indoorair/guidelines/hhfc/HHFC_guidelines.pdf (accessed on 14 July 2019).

8. Anenberg, S.C.; Balakrishnan, K.; Jetter, J.; Masera, O.; Mehta, S.; Moss, J.; Ramanathan, V. Cleaner cooking solutions to achieve health, climate, and economic co-benefits. Environ. Sci. Technol. 2013, 47, 3944-3952. [CrossRef] [PubMed]

9. Gordon, S.B.; Bruce, N.G.; Grigg, J.; Hibberd, P.L.; Kurmi, O.P.; Lam, K.H.; Mortimer, K.; Asante, K.P.; Balakrishnan, K.; Balmes, J.; et al. Respiratory risks from household air pollution in low and middle income countries. Lancet Respir. Med. 2014, 2, 823-860. [CrossRef]

10. Ezzati, M.; Saleh, H.; Kammen, D.M. The contributions of emissions and spatial microenvironments to exposure to indoor air pollution from biomass combustion in Kenya. Environ. Health Perspect. 2000, 108, 833-839. [CrossRef]

11. Edwards, R.D.; Smith, K.R.; Zhang, J.; Ma, Y. Models to predict emissions of health-damaging pollutants and global warming contributions of residential fuel/stove combinations in China. Chemosphere 2003, 50, 201-215. [CrossRef]

12. Ezzati, M.; Bailis, R.; Kammen, D.M.; Holloway, T.; Price, L.; Cifuentes, L.A.; Barnes, B.; Chaurey, A.; Dhanapala, K.N. Energy management and global health. Annu. Rev. Environ. Resour. 2004, 29, 383-420. [CrossRef]

13. United Nations Foundation. Global Alliance for Clean Cookstoves. Available online: http://www. cleancookstoves.org/the-alliance/ (accessed on 10 November 2016).

14. Roth, C.; Anderson, P.; McLaughlin, H.; Thomlinson, T.; Wilson, K. Micro-Gasification Cooking with Gas from Dry Biomass; Deutsche Gesellschaft für Internationale Zusammenarbeit (GIZ): Eschborn, Germany, 2014.

15. Martin, W.J., II; Glass, R.I.; Balbus, J.M.; Collins, F.S. A major environmental cause of death. Science 2011, 334, 180-181. [CrossRef]

16. Torres-Rojas, D.; Lehmann, J.; Hobbs, P.; Joseph, S.; Neufeldt, H. Biomass availability, energy consumption and biochar production in rural households of Western Kenya. Biomass Bioenergy 2011, 35, 3537-3546. [CrossRef]

17. Njenga, M.; Iiyama, M.; Jamnadass, R.; Helander, H.; Larsson, L.; de Leeuw, J.; Neufeldt, H.; Roing de Nowina, K.; Sundberg, C. Gasifier as a cleaner cooking system in rural Kenya. J. Clean. Prod. 2016, 121, 208-217. [CrossRef]

18. MacCarty, N.; Still, D.; Ogle, D. Fuel use and emissions performance of fifty cooking stoves in the laboratory and related benchmarks of performance. Energy Sustain. Dev. 2010, 14, 161-171. [CrossRef]

19. Abdelnour, S.; Pemberton-Piggot, C. For cooking and climate: Certify cookstoves in their contexts of use. Energy Res. Soc. Sci. 2018, 44, 196-198. [CrossRef]

20. CRA Kenya: Commission on Revenue Allocation. Available online: www.crakenya.org (accessed on 14 August 2018).

21. Mkuzi, H.; Mwaguni, S.; Danda, K. Resettling displaced people in a coastal zone mining project: Evaluating the agricultural and land use potential of the proposed resettlement site-A case of titanium mining in Kenya. J. Environ. Earth Sci. 2013, 3, 152-165.

22. Gitau, J.K.; Mutune, J.; Sundberg, C.; Mendum, R.; Njenga, M. Implications on Livelihoods and the Environment of Uptake of Gasifier Cook Stoves among Kenya's Rural Households. Appl. Sci. 2019, 9, 1205. [CrossRef]

23. Gitau, J.K.; Mutune, J.; Sundberg, C.; Mendum, R.; Njenga, M. Factors influencing the adoption of biochar producing gasifier cooking stoves by households in rural Kenya. Energy Sustain. Dev. 2019, 52, 63-71. [CrossRef]

24. Njenga, M.; Karanja, N.; Jamnadass, R.; Kithinji, J.; Sundberg, C.; Jirjis, R. Quality of briquettes produced locally from charcoal dust and sawdust in Kenya. J. Biobased Mater. Bioenergy 2013, 7, 315-322. [CrossRef]

25. WHO. Health Effects of Particulate Matter-Policy Implications for Countries in Eastern Europe, Caucasus and Central Asia; WHO Regional Office for Europe: Copenhagen, Denmark, 2013. Available online: http://www.euro. who.int/_data/assets/pdf_file/0006/189051/Health-effects-of-particulate-matter-final-Eng.pdf (accessed on 7 May 2019). 
26. WHO. Regional Office for Europe. WHO Guidelines for Indoor Air Quality: Selected Pollutants; WHO Regional Office for Europe: Copenhagen, Denmark, 2010. Available online: http://www.who. int/iris/handle/10665/260127 (accessed on 7 May 2019).

27. Occupational Safety and Health Administration. Permissible Exposure Limits, OSHA Annotated Table Z-1 ACGIH@Threshold Limit Values (TLVs@) (ACGIH®2019). Available online: https://www.osha.gov/dsg/ annotated-pels/tablez-1.html (accessed on 12 July 2019).

28. Taylor, A. W179 Wood Products Information-Moisture Content of 'Seasoned' Firewood; The University of Tennessee Agricultural Extension Service: Tennessee, TN, USA, 2010. Available online: http://trace.tennessee. edu/utk_agexfores/101 (accessed on 19 July 2019).

29. Sepp, S. Multiple-Household Fuel Use-A Balanced Choice between Firewood, Charcoal and LPG; Deutsche Gesellschaft für Internationale Zusammenarbeit (GIZ) GmbH: Addis Ababa, Ethiopia, 2014.

30. Fuwape, J.A.; Akindele, S.O. Biomass yield and energy value of some fast growing multipurpose trees in Nigeria. Biomass Bioenergy 1997, 12, 101-106. [CrossRef]

31. Nirmal, J.I.; Patel, K.; Kumar, R.N.; Kumar, B.R. An evaluation of fuelwood properties of some Aravally mountain tree and shrub species of Western India. Biomass Bioenergy 2011, 35, 411-414. [CrossRef]

32. Pennise, D.; Smith, K.; Kithinji, J.; Rezende, M.; Raad, T.; Zhang, J.; Fan, C. Emissions of greenhouse gases and other airborne pollutants from charcoal making in Kenya and Brazil. J. Geophys. Res. Atmos. 2001, 106, 24143-24155. [CrossRef]

33. Njenga, M.; Mendum, R.; Gitau, J.; Iiyama, M.; Jamnadass, R.; Watson, C. Trees on Farms Could Satisfy Household Firewood Needs; The Tree Farmers Magazine for Africa, Better Globe Forestry Ltd.: Nairobi, Kenya, 2017.

34. Food and Agriculture Organisation (FAO). Industrial Charcoal Making Mechanical Wood Products Branch, Forest Industries Division Forestry; FAO: Rome, Italy, 1985; p. 63.

35. Lotter, D.; Hunter, N.; Straub, M.; Msola, D. Microgasification cook stoves and pellet fuels from waste biomass: A cost and performance comparison with charcoal and natural gas in Tanzania. Afr. J. Environ. Sci. Technol. 2015, 9, 573-583.

36. Sundberg, C.; Karltun, E.; Gitau, J.; Kätterer, T.; Kimutai, G.; Mahmoud, Y.; Njenga, M.; Nyberg, G.; Roing de Nowina, K.; Roobroeck, D.; et al. $\mathrm{CO}_{2}$-Negative Cooking and Crop Cultivation in Smallholder Farms in Africa-The Potential Role of Biochar. Mitig. Adapt. Strateg. Glob. Chang. 2019, in press.

37. Duguma, A.; Minang, P.; Freeman, O.; Hager, H. System wide impacts of fuel usage patterns in the Ethiopian highlands: Potentials for breaking the negative reinforcing feedback cycles. Energy Sustain. Dev. 2014, 20, 77-85. [CrossRef]

38. Bizzarri, M. Safe Access to Firewood and Alternative Energy in Kenya: An Appraisal Report; World Food Programme and Womens Refugee Commission: Rome, Italy, 2010.

39. Singh, A.; Tuladhar, B.; Bajracharya, K.; Pillarisetti, A. Assessment of effectiveness of improved cook stoves in reducing indoor air pollution and improving health in Nepal. Energy. Sustain. Dev. 2012, 16, 406-414. [CrossRef]

40. GBD 2013 Risk Factors Collaborators. Global, regional, and national comparative risk assessment of 79 behavioural, environmental and occupational, and metabolic risks or clusters of risks in 188 countries, 1990-2013: A systematic analysis for the global burden of disease study 2013-The lancet. Lancet 2015, 386, 2287-2323. [CrossRef]

41. WHO. Burden of Disease from Household Air Pollution for 2012; WHO: Geneva, Switzerland, 2014.

42. WHO and Climate Clean Air Coalition. Air Pollution Climate and Health. 2016. Available online: https://www.who.int/sustainable-development/AirPollution_Climate_Health_Factsheet.pdf (accessed on 21 May 2019).

43. Loo, S.V.; Koppejan, J. (Eds.) The Handbook of Biomass Combustion and Co-firing; Earthscan: London, UK, 2008; pp. 112-120.

44. Arora, P.; Jain, S.; Sachdeva, K. Physical characterization of particulate matter emitted from wood combustion in improved and traditional cook stoves. Energy Sustain. Dev. 2013, 17, 497-503. [CrossRef]

45. Shankar, A.; Johnson, M.; Kay, E.; Pannu, R.; Beltramo, T.; Derby, E.; Harrel, S.; Davis, C.; Petach, H. Maximizing the benefits of improved cookstoves: Moving from acquisition to correct and consistent use. Glob. Health 2014, 2, 268-274. [CrossRef] [PubMed] 
46. Mekuria, W.; Noble, A. The role of biochar in ameliorating disturbed soils and sequestering soil carbon in tropical agricultural production systems. Appl. Environ. Soil Sci. 2013, 2013. [CrossRef]

47. Sujessy, L. A Climate Change Impact Assessment of Biochar System in Rural Kenya. Master's Thesis, Industrial Ecology, Second Cycle, Royal Institute of Technology (KTH), Stockholm, Sweden, 2018.

(C) 2019 by the authors. Licensee MDPI, Basel, Switzerland. This article is an open access article distributed under the terms and conditions of the Creative Commons Attribution (CC BY) license (http://creativecommons.org/licenses/by/4.0/). 